\title{
Dissolution Behavior of Nutrient Elements from Fertilizer Made of Steelmaking Slag, in an Irrigated Paddy Field Environment
}

\author{
$\mathrm{Xu} \mathrm{Gao}^{1} \cdot$ Nobuhiro Maruoka $^{1} \cdot$ Sun-joong Kim ${ }^{1} \cdot$ Shigeru Ueda $^{1} \cdot$ \\ Shin-ya Kitamura ${ }^{1}$
}

Published online: 5 October 2015

(C) The Minerals, Metals \& Materials Society (TMS) 2015

\begin{abstract}
To produce fertilizer made of steelmaking slag, the combination of mineralogical phases is necessary to be appropriate not only for refining at high temperature, but also for supplementing nutrient elements in paddy fields. In this research, first, the variations in the chemical composition and mineralogical structure of various brands of fertilizer made of steelmaking slag were investigated. The basicity $(\mathrm{CaO} /$ $\mathrm{SiO}_{2}$ ), free- $\mathrm{CaO}$ content, total $\mathrm{Fe}$ content, and $\mathrm{Fe}^{2+} / \mathrm{Fe}^{3+}$ ratio of fertilizer were found to vary widely depending on the brand. In addition, regarding the mineralogical phases, solid solution consisting of $2 \mathrm{CaO} \cdot \mathrm{SiO}_{2}$ and $3 \mathrm{CaO} \cdot \mathrm{P}_{2} \mathrm{O}_{5}, \mathrm{MgO}-$ $\mathrm{FeO}, \mathrm{CaO}-\mathrm{Fe}_{2} \mathrm{O}_{3}$, free $\mathrm{CaO}$, metallic $\mathrm{Fe}$, and the other phase which included liquid phases at refining temperature were observed. The mass fraction of each phase also varied depending on the brand. Second, the dissolution behavior of each mineralogical phase in the fertilizers into water that simulated the early stage of flooding condition was studied. Regarding the dissolution of $\mathrm{Ca}$, free $\mathrm{CaO}$ dissolved in a short time, and the solid solution of $2 \mathrm{CaO} \cdot \mathrm{SiO}_{2}$ and
\end{abstract}

The contributing editor for this article was Yiannis Pontikes.

$\mathrm{Xu}$ Gao

xgao@tagen.tohoku.ac.jp

Nobuhiro Maruoka

maruoka@tagen.tohoku.ac.jp

Sun-joong Kim

ksjoong@tagen.tohoku.ac.jp

Shigeru Ueda

tie@tagen.tohoku.ac.jp

Shin-ya Kitamura

kitamura@tagen.tohoku.ac.jp

1 Institute of Multidisciplinary Research for Advanced Materials, Tohoku University, 2-1-1, Katahira, Aoba-ku, Sendai 980-8577, Japan
$3 \mathrm{CaO} \cdot \mathrm{P}_{2} \mathrm{O}_{5}$ dissolved slowly. Fe barely dissolved from any mineralogical phase except the other phase which consisted of $\mathrm{CaO}-\mathrm{SiO}_{2}-\mathrm{FeO}$. A clear relationship was observed between the dissolution of $\mathrm{Fe}$ and the mass fraction of other phase as well as the ratio of $\mathrm{Fe}^{2+}$ to $\mathrm{Fe}^{3+}$ in $\mathrm{Fe}$ oxides in fertilizer made of steelmaking slag.

Keywords Fertilizer - Steelmaking slag · Paddy · Dissolution

\section{Introduction}

In Japan, fertilizer made of steelmaking slag is sold under various brand names. To register the category of by-product calcium fertilizer, in addition to the alkali content (35 mass\% or more), the maximum size (100\% is smaller than $1.7 \mathrm{~mm}$ and $85 \%$ is smaller than $600 \mu \mathrm{m}$ ) is the only other requirement [1]. Therefore, the manufactures of fertilizer production should mainly be crashing and classifying. However, the composition and mineralogical structure of steelmaking slag varied with the steelmaking and slag treatment processes $[2$, 3]. Therefore, the dissolution behaviors of nutrient elements may be different for each brand.

The dissolution behaviors of various elements from steelmaking slag have been reported under sea water conditions [4] or the standard condition (to investigate the leaching behavior which determined by the environmental regulation) [5]. For agricultural utilization, fertilizer made of steelmaking slag can provide many necessary elements, such as $\mathrm{Ca}, \mathrm{Si}$, $\mathrm{Fe}, \mathrm{Mg}, \mathrm{P}$, and $\mathrm{Mn}[6]$, and the positive role of steelmaking slag in agriculture has been expected. In paddy field, the improvement in paddy growth and yield after the application of fertilizer made of steelmaking slag has been confirmed [7]. Therefore, to investigate the effectiveness of fertilizers made 
of steelmaking slag in paddy fields, current authors have measured the dissolution behaviors into pore water among paddy soils [9, 10]. In this experimental system involving soil, it is difficult to clarify the dissolution behavior of the fertilizer itself, as both the $\mathrm{pH}$ and oxidation potential widely change during experiments, and also the capacity of soil to absorb the dissolved elements is extremely large. In addition, the role of each mineralogical phase in the dissolution of each element is not clear. To produce fertilizer made of steelmaking slag, the combination of mineralogical phases should be appropriate not only for refining at high temperature but also for supplementing nutrient elements in paddy fields.

With this background, in this research, first, the variations in the chemical composition and mineralogical structure of several brands of fertilizer made of steelmaking slag were investigated. Second, the dissolution behavior of each mineralogical phase appearing in fertilizer made of steelmaking slag into water, that simulated the early stage of flooding conditions, was investigated. Next, by comparing these results with the dissolution behavior of fertilizer made of steelmaking slag, the role of each phase in the dissolution of each element was discussed.

\section{Composition and Structure of Fertilizer Made of Steelmaking Slag}

\section{Analysis Method}

Steelmaking slags from 11 of the 16 integrated steelmaking mills in Japan are utilized as fertilizer. In most cases, steelmaking slag is sold to a subcontracting company that has a license to produce fertilizer. These companies deal in fertilizer made of steelmaking slag using different brand names. Eleven samples of fertilizer made of steelmaking slag were collected to investigate the differences in composition and mineralogical structure.

Chemical analysis of the samples was conducted by Nittetu-Techno Research Corporation. The total Fe, $\mathrm{CaO}$, $\mathrm{SiO}_{2}, \mathrm{Al}_{2} \mathrm{O}_{3}, \mathrm{MgO}, \mathrm{MnO}$, and $\mathrm{P}_{2} \mathrm{O}_{5}$ contents were analyzed by X-ray fluorescent spectroscopy (XRF). The sample was dried and ground into fine powder, and then pressed into briquettes before analysis [11]. Metallic Fe and FeO were analyzed by titration [12]. Free $\mathrm{CaO}$ and free $\mathrm{MgO}$ were analyzed by ICP-AES after dissolution by ethylene glycol [13] and ammonium nitrate [14], respectively. The mineralogical structure was measured by electron probe microanalyzer (EPMA) and X-ray diffraction (XRD).

\section{Results and Discussion}

Typical chemical compositions are shown in Table 1. Because several brands of fertilizer made of steelmaking slag showed similar results, only the results of 8 brands (A to $\mathrm{H})$ are shown in this paper. Every sample contained $\mathrm{CaO}$, $\mathrm{SiO}_{2}$, and $\mathrm{Fe}$ oxide as the main components, with several percents of $\mathrm{Al}_{2} \mathrm{O}_{3}, \mathrm{MgO}, \mathrm{MnO}$, and $\mathrm{P}_{2} \mathrm{O}_{5}$. The ratio of $\mathrm{Fe}_{2} \mathrm{O}_{3}$ to $\mathrm{FeO}$ was higher than that of steelmaking slag sampled just after refining, because of oxidation during slag processing.

The variations in the free $\mathrm{CaO}$ content with basicity (mass ratio of $\mathrm{CaO}$ to $\mathrm{SiO}_{2}$ ) and in the $\mathrm{Fe}^{2+} / \mathrm{Fe}^{3+}$ ratio with total Fe content are shown in Figs. 1 and 2, respectively. A relationship between the basicity and free $\mathrm{CaO}$ content was found. The basicity varied from 1.4 to 4.1 , and the free $\mathrm{CaO}$ content ranged from 1.6 to 8.5 mass $\%$ depending on the brand. The variations in the total $\mathrm{Fe}$ content and $\mathrm{Fe}^{2+}$ / $\mathrm{Fe}^{3+}$ ratio are 10.2-23.5 mass $\%$ and $0.8-3.2$, respectively.

Typical cross sections of fertilizer particles observed by EPMA are shown in Fig. 3, where $\mathrm{C}$ is the abbreviation of $\mathrm{CaO}, \mathrm{S}$ is $\mathrm{SiO}_{2}, \mathrm{M}$ is $\mathrm{MgO}, \mathrm{F}$ is $\mathrm{FeO}, \mathrm{A}$ is $\mathrm{Al}_{2} \mathrm{O}_{3}$, and $\mathrm{P}$ is $\mathrm{P}_{2} \mathrm{O}_{5}$. In every sample, $2 \mathrm{CaO} \cdot \mathrm{SiO}_{2}(\mathrm{C} 2 \mathrm{~S}), \mathrm{MgO}-\mathrm{FeO}_{x}(\mathrm{MF})$, and $\mathrm{CaO}-\mathrm{FeO}_{x}(\mathrm{CF})$ phases were commonly observed. In addition to these phases which could be easily observed within all fertilizer samples, phases that could be considered as liquid phases at the refining temperature were also observed, and these phases are defined as the 'other phase' in this study.

By quantitative analysis of each phase using EPMA and the chemical compositions of the samples, the mass fraction of each phase was estimated. In this calculation, $2 \mathrm{CaO} \cdot \mathrm{SiO}_{2}$, which forms the solid solution with $3 \mathrm{CaO} \cdot \mathrm{P}_{2} \mathrm{O}_{5}(\mathrm{C} 2 \mathrm{~S}-\mathrm{C} 3 \mathrm{P})$, and the $\mathrm{MF}, \mathrm{CF}$, free $\mathrm{CaO}$, metallic $\mathrm{Fe}$, and other phase were considered as mineralogical phases. The other phase was separated into three categories according to the main compounds, which were $\mathrm{CaO}-\mathrm{SiO}_{2}-\mathrm{FeO}_{x}(\mathrm{C}-\mathrm{S}-\mathrm{F}), \mathrm{CaO}-\mathrm{SiO}_{2}-$ $\mathrm{Al}_{2} \mathrm{O}_{3}(\mathrm{C}-\mathrm{S}-\mathrm{A})$, and the remaining phase. The average composition of each phase was calculated as the average values of several positions on the phases of the same category.

In the following calculation, the mass fractions of each mineralogical phase except for free $\mathrm{CaO}$ and metallic $\mathrm{Fe}$ were considered. The mass balance of an oxide $\mathrm{NO}_{n}$ is written in Eq. (1). The concentration of $\mathrm{NO}_{n}$ in slag measured by chemical analysis is $\mathrm{NO}_{n}^{\mathrm{T}}$ mass $\%$, and the concentrations of $\mathrm{NO}_{n}$ in the C2S-C3P, CF, MF, C-S-F, C-S$\mathrm{A}$, and the remaining phase measured by EPMA are $\mathrm{NO}_{n}^{\mathrm{C} 2 \mathrm{~S}}$ $\operatorname{mass} \%, \mathrm{NO}_{n}^{\mathrm{CF}} \operatorname{mass} \%, \mathrm{NO}_{n}^{\mathrm{MF}} \operatorname{mass} \%, \mathrm{NO}_{n}^{\mathrm{C}-\mathrm{S}-\mathrm{F}} \operatorname{mass} \%$, $\mathrm{NO}_{n}^{\mathrm{C}-\mathrm{S}-\mathrm{A}}$ mass $\%$, and $\mathrm{NO}_{n}^{\text {rem }}$ mass $\%$, respectively. The mass fractions of the $\mathrm{C} 2 \mathrm{~S}-\mathrm{C} 3 \mathrm{P}, \mathrm{CF}, \mathrm{MF}, \mathrm{C}-\mathrm{S}-\mathrm{F}, \mathrm{C}-\mathrm{S}-\mathrm{A}$, and remaining phase are, $V^{\mathrm{C} 2 \mathrm{~S}}, V^{\mathrm{CF}}, V^{\mathrm{MF}}, V^{\mathrm{C}-\mathrm{S}-\mathrm{F}}$, $V^{\mathrm{C}-\mathrm{S}-\mathrm{A}}$, and $V^{\mathrm{rem}}$, respectively.

$$
\begin{aligned}
\mathrm{NO}_{n}^{\mathrm{T}}= & V^{\mathrm{C} 2 \mathrm{~S}} \times \mathrm{NO}_{n}^{\mathrm{C} 2 \mathrm{~S}}+V^{\mathrm{CF}} \times \mathrm{NO}_{n}^{\mathrm{CF}}+V^{\mathrm{MF}} \times \mathrm{NO}_{n}^{\mathrm{MF}} \\
& +V^{\mathrm{CSF}} \times \mathrm{NO}_{n}^{\mathrm{CSF}}+V^{\mathrm{CSA}} \times \mathrm{NO}_{n}^{\mathrm{CSA}}+V^{\mathrm{rem}} \times \mathrm{NO}_{n}^{\mathrm{rem}}
\end{aligned}
$$


Table 1 Composition of fertilizers made of steelmaking slag (mass\%)

\begin{tabular}{lcccccccccccc}
\hline Brands & $\mathrm{CaO}$ & $\mathrm{SiO}_{2}$ & $\mathrm{~T}-\mathrm{Fe}$ & $\mathrm{FeO}$ & $\mathrm{Fe}_{2} \mathrm{O}_{3}$ & $\mathrm{M}-\mathrm{Fe}$ & $\mathrm{Al}_{2} \mathrm{O}_{3}$ & $\mathrm{MnO}$ & $\mathrm{MgO}$ & $\mathrm{P}_{2} \mathrm{O}_{5}$ & f-CaO & f-MgO \\
\hline A & 31.3 & 17.5 & 22.9 & 20.7 & 7.2 & 1.8 & 3.5 & 5.9 & 5.9 & 2.8 & 1.6 & 0.018 \\
$\mathrm{~B}$ & 42.6 & 11.4 & 19.0 & 10.3 & 14.0 & 1.2 & 1.5 & 4.0 & 8.9 & 2.2 & 6.9 & 0.014 \\
$\mathrm{C}$ & 47.6 & 11.5 & 17.6 & 10.9 & 11.1 & 1.4 & 3.0 & 1.6 & 5.6 & 2.6 & 8.5 & 0.010 \\
$\mathrm{D}$ & 46.2 & 18.3 & 10.2 & 5.2 & 7.5 & 0.9 & 6.1 & 3.4 & 4.4 & 1.4 & 5.3 & 0.006 \\
E & 33.7 & 15.1 & 23.5 & 12.7 & 10.8 & 6.1 & 3.4 & 2.5 & 7.3 & 3.3 & 2.6 & 0.017 \\
$\mathrm{~F}$ & 39.6 & 22.3 & 11.2 & 6.46 & 5.4 & 2.5 & 6.0 & 2.4 & 4.8 & 1.3 & 1.8 & 0.011 \\
$\mathrm{G}$ & 38.6 & 11.7 & 16.1 & 9.77 & 10.7 & 1.0 & 4.3 & 4.8 & 4.7 & 1.7 & 2.3 & 0.004 \\
$\mathrm{H}$ & 31.3 & 19.0 & 22.1 & 19.2 & 7.3 & 2.1 & 3.4 & 5.4 & 6.3 & 3.2 & 2.1 & 0.004 \\
\hline
\end{tabular}

${ }^{\mathrm{a}} \mathrm{f}-\mathrm{CaO}, \mathrm{f}-\mathrm{MgO}$ stand for free- $\mathrm{CaO}$ and free- $\mathrm{MgO}$, respectively

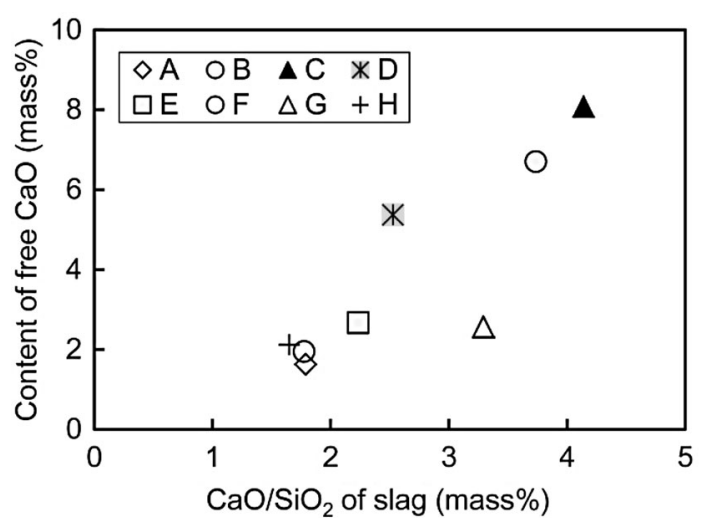

Fig. 1 Relationship between basicity $\left(\mathrm{CaO} / \mathrm{SiO}_{2}\right)$ and free-CaO content of various brands of fertilizers made of steelmaking slag

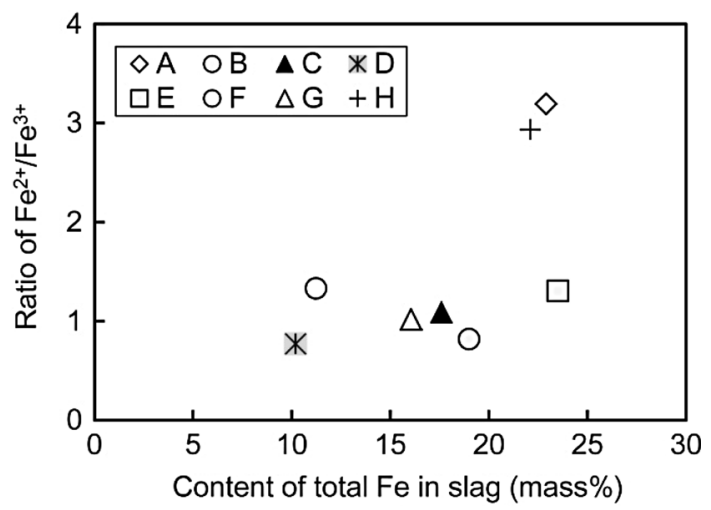

Fig. 2 Relationship between total $\mathrm{Fe}$ content and the $\mathrm{Fe}^{2+} / \mathrm{Fe}^{3+}$ ratio of various brands of fertilizers made of steelmaking slag

The mass fraction of each phase can be calculated, when this equation is written for $\mathrm{CaO}, \mathrm{SiO}_{2}, \mathrm{FeO}, \mathrm{MgO}, \mathrm{P}_{2} \mathrm{O}_{5}$, $\mathrm{MnO}$, and $\mathrm{Al}_{2} \mathrm{O}_{3}$ and these simultaneous equations are solved. Although each slag contained $\mathrm{FeO}$ and $\mathrm{Fe}_{2} \mathrm{O}_{3}$, to calculate Eq. (1) for $\mathrm{FeO}, \mathrm{FeO}^{\mathrm{T}}$ was calculated by conversion from the analyzed total $\mathrm{Fe}$ value.

The mass fractions of typical mineralogical phases are summarized in Table 2 . In every brand, the $\mathrm{C} 2 \mathrm{~S}-\mathrm{C} 3 \mathrm{P}$ phase was the major phase, with a mass fraction of 22.5 to nearly 47.2 depending on the basicity. The mass fractions of the CF, MF, and other phase varied in each brand. The compositions of the other phase are summarized in Fig. 4 by projection in the phase diagram of the $\mathrm{CaO}-\mathrm{SiO}_{2}-\mathrm{FeO}$ system (a) and the $\mathrm{CaO}-\mathrm{SiO}_{2}-\mathrm{Al}_{2} \mathrm{O}_{3}$ system (b). Depending on the cooling conditions of the slag, in some cases, the other phase was not uniform, and many small phases were precipitated thus the composition was widely scattered. In some samples, the $\mathrm{Al}_{2} \mathrm{O}_{3}$ content was so high that this brand would be considered a mixture of steelmaking slag with blast furnace slag. In other samples, the other phase was glassy, and its composition was located in the region of liquid composition at the refining temperature.

\section{Dissolution Behavior of Nutrient Elements}

\section{Experimental Method}

To clarify the dissolution behavior, oxides with the same compositions as the mineralogical phases identified by EPMA were synthesized. The composition of each synthetic mineralogical phase is shown in Table 3; the values were the average composition of phases with the same category for all tested fertilizers measured by EPMA. Initially, $\mathrm{CaCO}_{3}$ was sintered at $1273 \mathrm{~K}$ to make $\mathrm{CaO}$, and $\mathrm{Fe}_{2} \mathrm{O}_{3}$ was reduced at $1723 \mathrm{~K}$ by metallic $\mathrm{Fe}$ to make $\mathrm{FeO}$. For other compounds of the synthesize phases, commercial reagents were used. To make $\mathrm{C} 2 \mathrm{~S}-\mathrm{C} 3 \mathrm{P}$, after $\mathrm{CaO}$ and $\mathrm{SiO}_{2}$ were sintered for $48 \mathrm{~h}$ at $1873 \mathrm{~K}$ to make $2 \mathrm{CaO} \cdot \mathrm{SiO}_{2}$, the mixture of $2 \mathrm{CaO} \cdot \mathrm{SiO}_{2}$ and the reagents of $3 \mathrm{CaO} \cdot \mathrm{P}_{2} \mathrm{O}_{5}, \mathrm{FeO}$, and $\mathrm{Al}_{2} \mathrm{O}_{3}$ were sintered for $48 \mathrm{~h}$ at $1873 \mathrm{~K}$. To make $\mathrm{MF}$ and $\mathrm{CF}$, a mixture of $\mathrm{MgO}$, $\mathrm{FeO}, \mathrm{MnO}$ and a mixture of $\mathrm{CaO}, \mathrm{Al}_{2} \mathrm{O}_{3}$, and $\mathrm{Fe}_{2} \mathrm{O}_{3}$ were sintered for $48 \mathrm{~h}$ at 1573 and $1473 \mathrm{~K}$, respectively. To make free $\mathrm{CaO}$, a small amount of $\mathrm{FeO}, \mathrm{MnO}$, and $\mathrm{MgO}$ were mixed with $\mathrm{CaO}$ and then sintered at $1273 \mathrm{~K}$ for $48 \mathrm{~h}$. To make the $\mathrm{C}-\mathrm{S}-\mathrm{F}$ phase, as brand A showed a higher fraction of the $\mathrm{C}-\mathrm{S}-\mathrm{F}$ phase according to Table 2, the average composition of $\mathrm{C}-\mathrm{S}-\mathrm{F}$ phase in brand $\mathrm{A}$ was selected for 

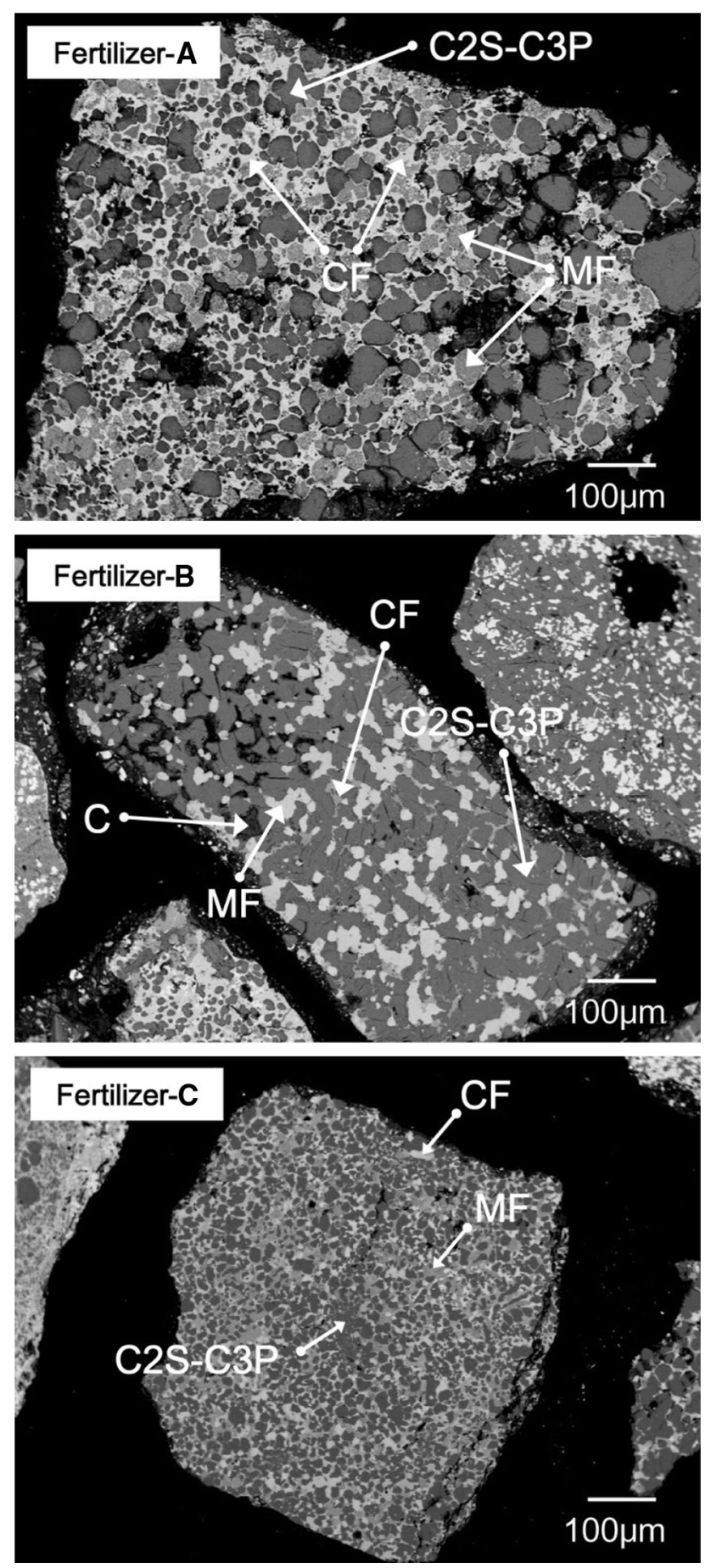

Fig. 3 Typical cross sections of fertilizer particles observed by EPMA

synthesis in this study. The raw materials for synthesizing the $\mathrm{C}-\mathrm{S}-\mathrm{F}$ phase were $\mathrm{CaO}, \mathrm{SiO}_{2}, 3 \mathrm{CaO} \cdot \mathrm{P}_{2} \mathrm{O}_{5}, \mathrm{MgO}, \mathrm{MnO}$, $\mathrm{Al}_{2} \mathrm{O}_{3}$, and $\mathrm{Fe}$ oxide. In particular, for $\mathrm{Fe}$ oxide, because the $\mathrm{Fe}^{2+} / \mathrm{Fe}^{3+}$ ratio in the $\mathrm{C}-\mathrm{S}-\mathrm{F}$ phase was impossible to evaluate, either $\mathrm{FeO}$ or $\mathrm{Fe}_{2} \mathrm{O}_{3}$ was used during synthesis. Therefore, the $\mathrm{C}-\mathrm{S}-\mathrm{F}$ phase was prepared as $\mathrm{C}-\mathrm{S}-\mathrm{Fe}^{3+}$ or $\mathrm{C}-\mathrm{S}-\mathrm{Fe}^{2+}$, as shown in Table 3. The total Fe contents of both
Table 2 Mass fractions of mineralogical phases in fertilizers made of steelmaking slag (mass\%)

\begin{tabular}{llrrlll}
\hline Brand & C2S-C3P & CF & MF & \multicolumn{2}{l}{ Others } \\
\cline { 5 - 7 } & & & & C-S-A & C-S-F & Remained \\
\hline A & 30.6 & 7.7 & 9.5 & 0.5 & 29.4 & 18.8 \\
B & 37.4 & 33.8 & 13.4 & - & 2.9 & 4.5 \\
C & 47.2 & 24.8 & 7.3 & 5.0 & 4.4 & - \\
D & 29.8 & 26.4 & 4.7 & 23.4 & - & 9.5 \\
E & 28.7 & 20.1 & 22.2 & 2.6 & 17.0 & 1.1 \\
F & 22.5 & 19.5 & 6.1 & 33.2 & 13.9 & 0.6 \\
G & 31.8 & 32.7 & 25.1 & - & 7.1 & - \\
H & 25.3 & 4.5 & 16.9 & 15.8 & 21.2 & 12.3 \\
\hline
\end{tabular}
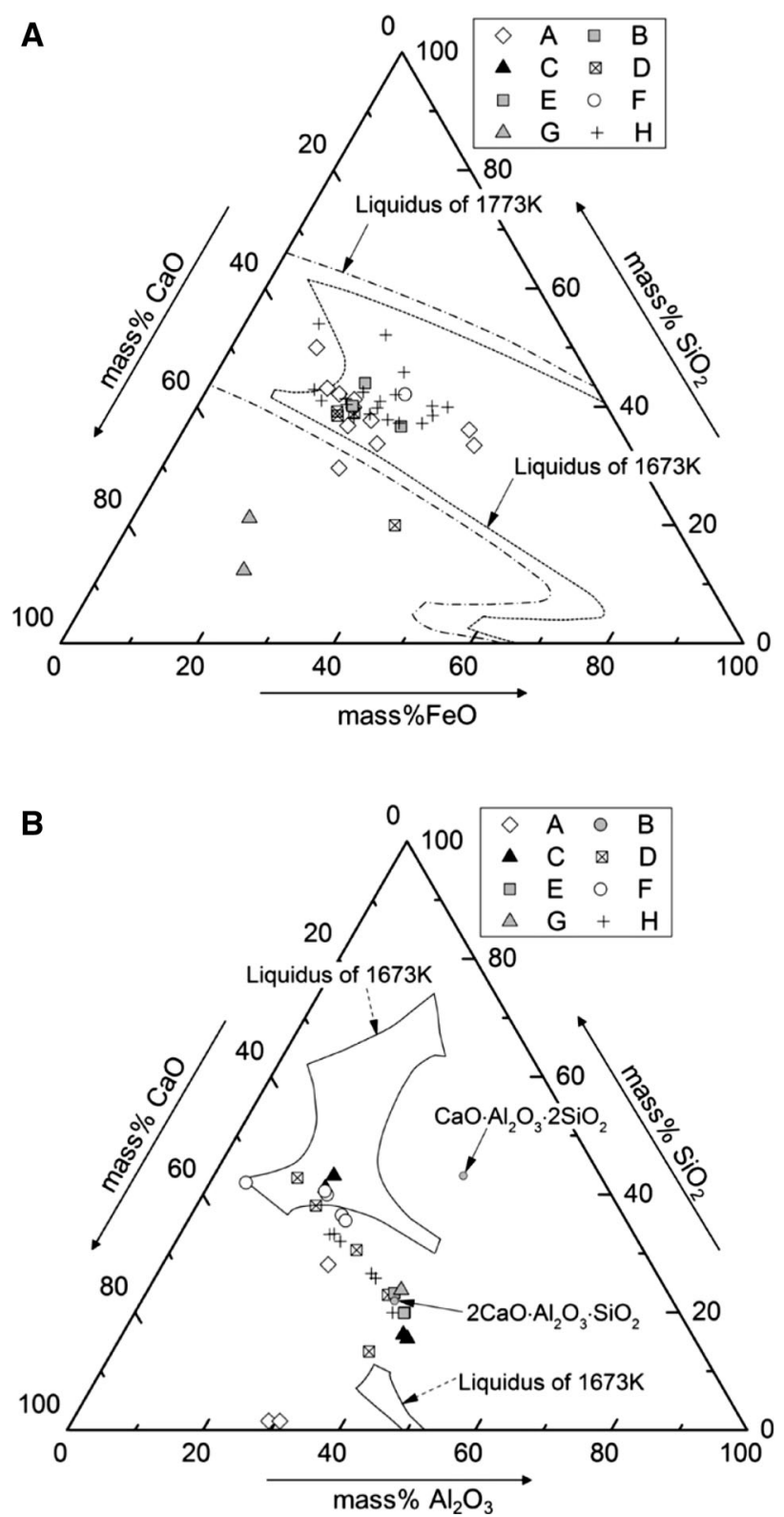

Fig. 4 Projection of the other phase in the phase diagram of the $\mathrm{CaO}-\mathrm{SiO}_{2}-\mathrm{FeO}$ (a) and the $\mathrm{CaO}-\mathrm{SiO}_{2}-\mathrm{Al}_{2} \mathrm{O}_{3}$ ternary system (b), mass $\%$ 
Table 3 Composition of synthetic mineralogical phases (mass\%)

\begin{tabular}{lclllllll}
\hline & $\mathrm{CaO}$ & $\mathrm{SiO}_{2}$ & $\mathrm{MgO}$ & $\mathrm{P}_{2} \mathrm{O}_{5}$ & $\mathrm{MnO}$ & $\mathrm{FeO}$ & $\mathrm{Fe}_{2} \mathrm{O}_{3}$ & $\mathrm{Al}_{2} \mathrm{O}_{3}$ \\
\hline $\mathrm{C} 2 \mathrm{~S}-\mathrm{C} 3 \mathrm{P}$ & 64.1 & 27.7 & & 6.2 & & 1.4 & & 0.5 \\
$\mathrm{CF}$ & 38.7 & - & - & - & - & - & 55.8 & 5.5 \\
$\mathrm{f}-\mathrm{CaO}$ & 82.0 & - & 1.1 & - & 6.4 & 10.5 & - & - \\
$\mathrm{MF}$ & 3.2 & - & 26.1 & - & 9.6 & 61.1 & - & - \\
$\mathrm{C}-\mathrm{S}-\mathrm{Fe}^{2+\mathrm{a}}$ & 28.8 & 29.3 & 4.0 & 3.6 & 7.0 & 24.8 & - & 2.5 \\
$\mathrm{C}-\mathrm{S}-\mathrm{Fe}^{3+\mathrm{a}}$ & 28.3 & 28.5 & 7.5 & 3.5 & 6.8 & - & 22.7 & 2.7 \\
\hline
\end{tabular}

${ }^{\text {a }} \mathrm{C}-\mathrm{S}-\mathrm{Fe}^{2+}$ means $\mathrm{C}-\mathrm{S}-\mathrm{F}$ phase using $\mathrm{FeO}$ as iron oxide, while $\mathrm{C}-\mathrm{S}-\mathrm{Fe}^{3+}$ using $\mathrm{Fe}_{2} \mathrm{O}_{3}$ as iron oxide

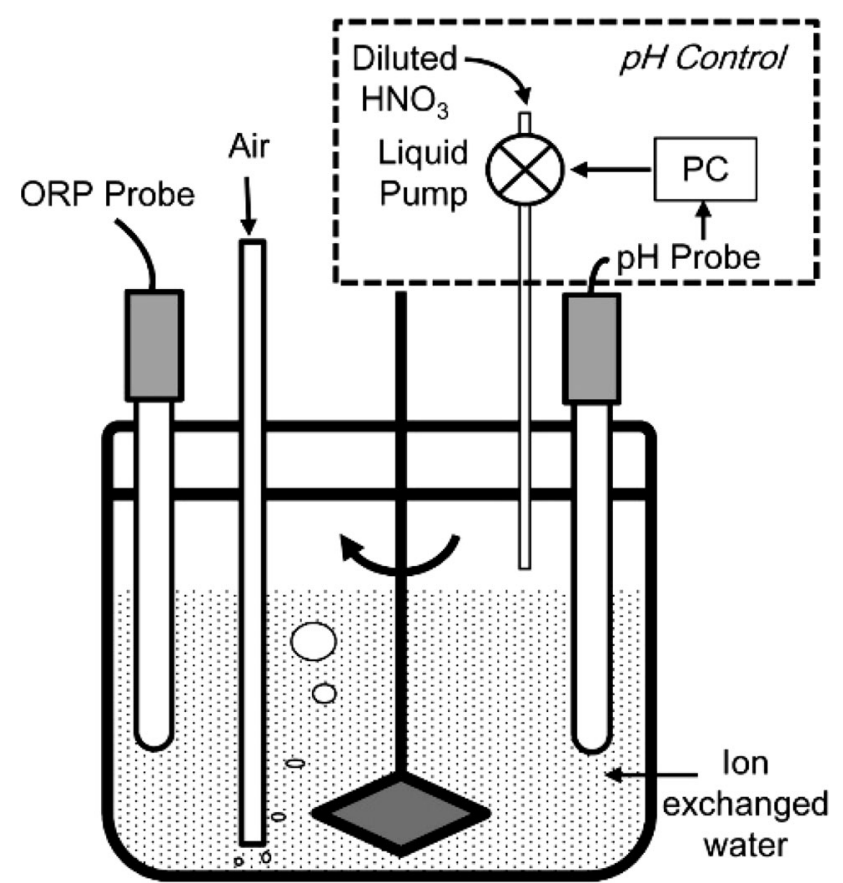

Fig. 5 Experimental setup for leaching test

$\mathrm{C}-\mathrm{S}-\mathrm{Fe}^{3+}$ and $\mathrm{C}-\mathrm{S}-\mathrm{Fe}^{2+}$ were the same. In detail, the oxide mixture for preparing $\mathrm{C}-\mathrm{S}-\mathrm{Fe}^{2+}$ was melted for $3 \mathrm{~h}$ at $1673 \mathrm{~K}$ within an $\mathrm{Fe}$ crucible and then quenched by water. For the $\mathrm{C}-\mathrm{S}-\mathrm{Fe}^{3+}$ phase, oxide mixture containing $\mathrm{Fe}_{2} \mathrm{O}_{3}$ was melted for $3 \mathrm{~h}$ at $1673 \mathrm{~K}$ using a $\mathrm{MgO}$ crucible and then quenched by He gas spray.

The experimental setup for the leaching test is shown in Fig. 5. The leaching test was conducted using air-saturated water with a controlled $\mathrm{pH}$ of 5 . The air-saturation and $\mathrm{pH}$ were determined to simulate the soil solution of paddy fields in the early period after flooding [8]. Before the leaching experiments, $400 \mathrm{~mL}$ of ion-exchanged water was poured into a Teflon container and kept at $298 \mathrm{~K}$ using an isothermal water bath. Then air bubbling as well as agitation by a mechanical stirrer began. After air saturation was established by air bubbling for about $30 \mathrm{~min}, 1 \mathrm{~g}$ of solid sample (smaller than $53 \mu \mathrm{m}$ ), which was either the synthetic mineralogical phase or the fertilizer made of

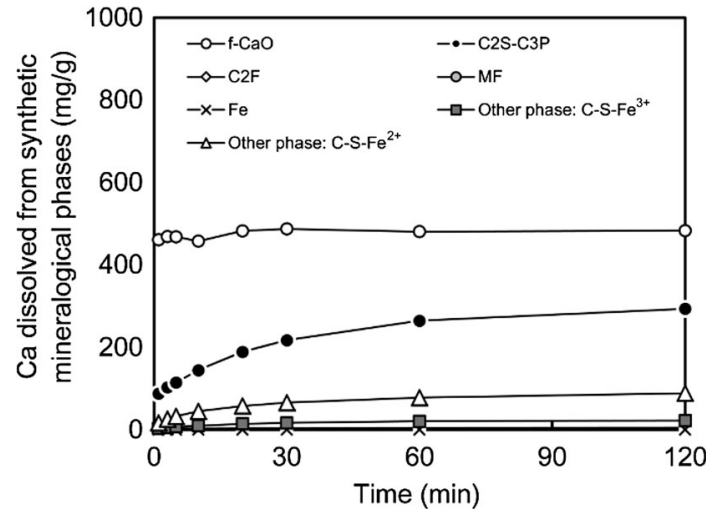

Fig. 6 Leaching behavior of $\mathrm{Ca}$ in aqueous solution from each synthetic mineralogical phase

steelmaking slag, was dropped into the water. At the meantime, the $\mathrm{pH}$ control system was launched. Dilute nitric acid solution was used to control the $\mathrm{pH}$. When the $\mathrm{pH}$ had decreased to 5, sampling of the solution was started and then repeated at certain intervals. The sampled solution was analyzed by ICP-AES, and the residue after leaching was collected and analyzed by XRD.

\section{Results and Discussion}

The leaching behavior of $\mathrm{Ca}$ when $1 \mathrm{~g}$ of each mineralogical phase is added to $400 \mathrm{~mL}$ of aqueous solution is shown in Fig. 6. It is clear that free $\mathrm{CaO}$ dissolved completely in a short time, and the $\mathrm{C} 2 \mathrm{~S}-\mathrm{C} 3 \mathrm{P}$ phase dissolved slowly for about $1 \mathrm{~h}$. In contrast, $\mathrm{Ca}$ did not dissolve from the $\mathrm{CF}$ or MF phase. In addition, $\mathrm{Ca}$ was also supplied from the $\mathrm{C}-\mathrm{S}-$ $\mathrm{F}$ phase when $\mathrm{FeO}$ was used as the $\mathrm{Fe}$ oxide $\left(\mathrm{C}-\mathrm{S}-\mathrm{Fe}^{2+}\right)$, but the dissolution was negligible when $\mathrm{Fe}_{2} \mathrm{O}_{3}$ was used $(\mathrm{C}-$ $\left.\mathrm{S}-\mathrm{Fe}^{3+}\right)$. By using this result, the dissolution mass of $\mathrm{Ca}$ $\left(D_{\mathrm{Ca}}^{t}\right)$ from $1 \mathrm{~g}$ of fertilizer made of steelmaking slag can be estimated using Eq. (2), where, $D$ is the dissolution mass, $\mathrm{mg} / \mathrm{g} ; m_{\mathrm{F}}$ is the amount of fertilizer added to water, $\mathrm{g} ; V$ is the mass ratio of mineralogical phases as shown in Table 2, mass $\%$ (note that $V^{\text {free-Ca }}$ was the mass ratio of free $\mathrm{CaO}$ shown in Table 1); and $t$ is the leaching time, min. 


$$
\begin{aligned}
D_{\mathrm{Ca}}^{t}= & m_{\mathrm{F}} \times V^{\mathrm{free}-\mathrm{Ca}} \times D_{\text {free- } \mathrm{Ca}}^{t}+m_{\mathrm{F}} \times V^{\mathrm{C} 2 \mathrm{~S}} \times D_{\mathrm{C} 2 \mathrm{~S}}^{t}+m_{\mathrm{F}} \\
& \times V^{\mathrm{CF}} \times D_{\mathrm{CF}}^{t}+m_{\mathrm{F}} \times V^{\mathrm{MF}} \times D_{\mathrm{MF}}^{t}+m_{\mathrm{F}} \times V^{\mathrm{C}-\mathrm{S}-\mathrm{Fe}^{2+}} \\
& \times D_{\mathrm{C}-\mathrm{S}-\mathrm{Fe}^{2+}}^{t}\left(\text { or } m_{\mathrm{F}} \times V^{\mathrm{C}-\mathrm{S}-\mathrm{Fe}^{3+}} \times D_{\mathrm{C}-\mathrm{S}-\mathrm{Fe}^{3+}}^{t}\right)
\end{aligned}
$$

The results when $t$ is 120 min are shown in Fig. 7, in comparison with the actual leaching behaviors of fertilizer made of steelmaking slag. In this graph, two columns are shown as the amount of dissolved $\mathrm{Ca}$ from either the $\mathrm{C}-\mathrm{S}-$ $\mathrm{Fe}^{2+}$ or $\mathrm{C}-\mathrm{S}-\mathrm{Fe}^{3+}$ phase, because the ratio of $\mathrm{Fe}^{2+}$ to $\mathrm{Fe}^{3+}$ in the $\mathrm{C}-\mathrm{S}-\mathrm{F}$ phase of the actual fertilizer was unknown. The dissolved mass of Ca calculated by Eq. (2) agreed with that in each brand. The total mass of dissolved $\mathrm{Ca}$ was large in the brands that had a high content of free $\mathrm{CaO}$ and high basicity, for instance, brands B and C.

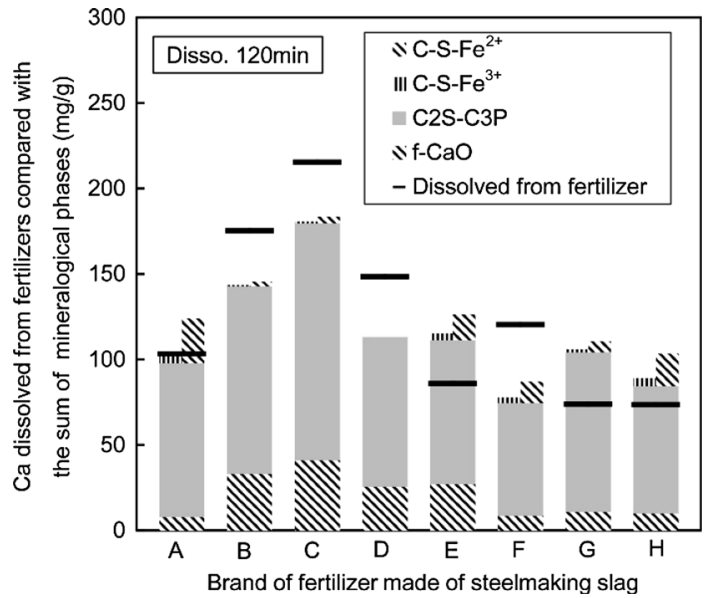

Fig. 7 Mass of Ca dissolved from each fertilizer made of steelmaking slag, comparing with the calculated value

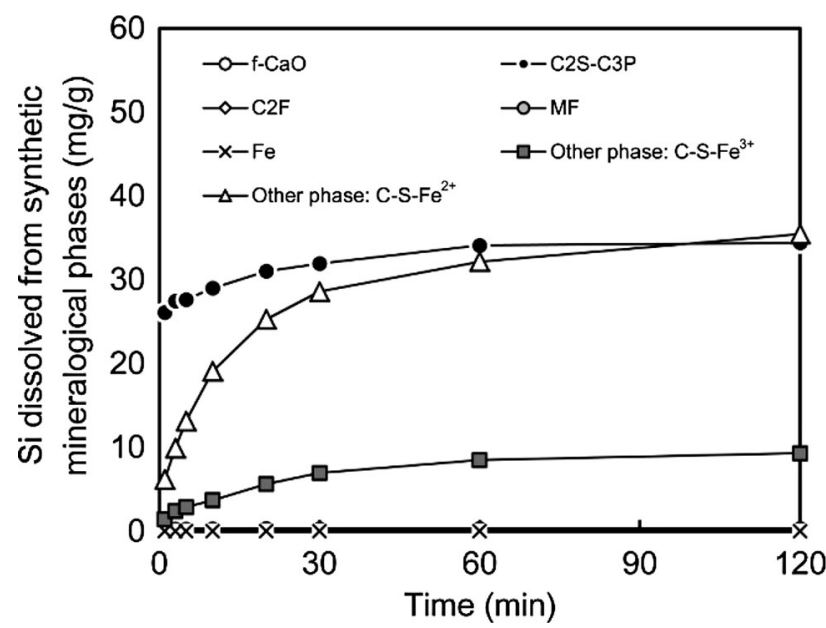

Fig. 8 Leaching behavior of $\mathrm{Si}$ in aqueous solution from each mineralogical phase
The leaching behavior of $\mathrm{Si}$ when $1 \mathrm{~g}$ of each mineralogical phase is added to $400 \mathrm{~mL}$ of aqueous solution is shown in Fig. 8. The source of soluble Si was C2S-C3P and the $\mathrm{C}-\mathrm{S}-\mathrm{Fe}^{2+}$ phase. The leaching behavior of $\mathrm{Si}$ from fertilizer made of steelmaking slag is shown in Fig. 9 in comparison with the values calculated by the same method as in Eq. (2). The dissolved mass of Si after $120 \mathrm{~min}$ for each brand was similar, and the calculated values were smaller than the actual dissolution masses for most brands. The reason is considered to be that the solubility of $\mathrm{Si}$ in water should be controlled by a hydro-compound that formed after the dissolution of $\mathrm{Si}$, and a high concentration of $\mathrm{Ca}^{2+}$ decreased the content of soluble $\mathrm{Si}$ in water. Equations (3) to (5) are introduced to enhance the understanding of this explanation $[15,16]$, and the calculated

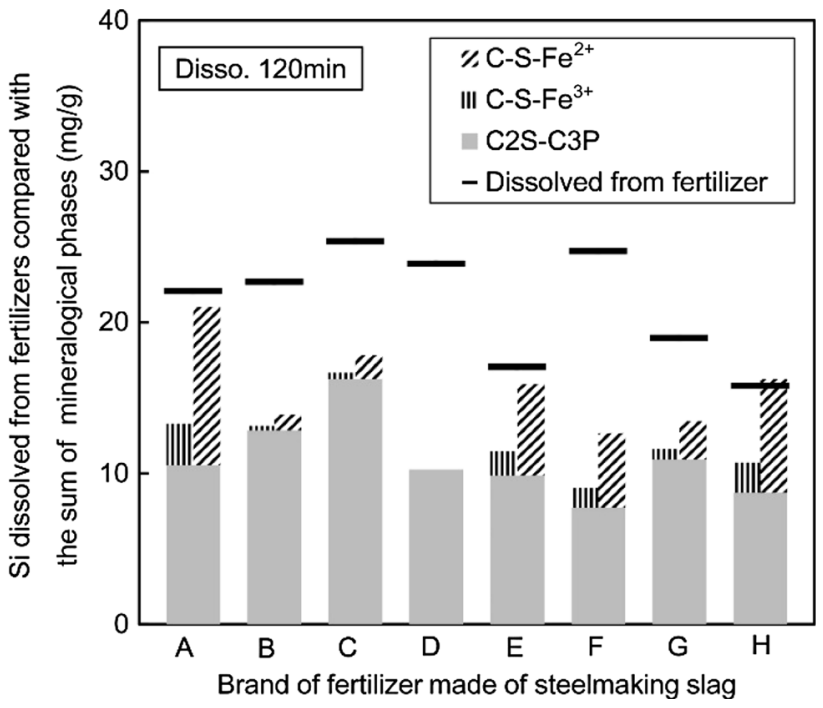

Fig. 9 Mass of Si dissolved from each fertilizer made of steelmaking slag, comparing with the calculated value

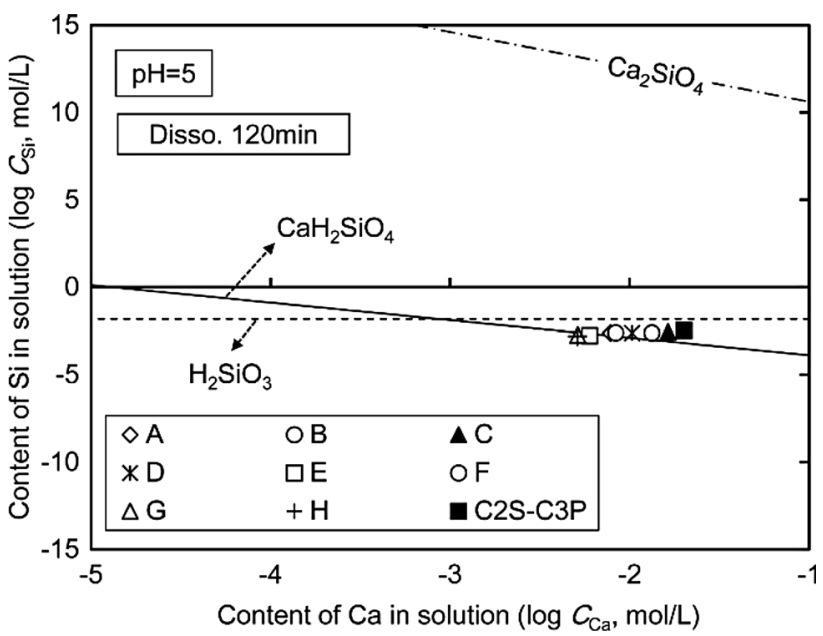

Fig. 10 Effect of dissolved $\mathrm{Ca}$ on the solubility of $\mathrm{Si}$ in aqueous solution, comparing with experimental results at $120 \mathrm{~min}$ 
Table 4 Estimated activity coefficient of ions

\begin{tabular}{ll}
\hline Species & Activity coefficient \\
\hline $\mathrm{H}_{2} \mathrm{SiO}_{3}{ }^{0}$ & 1 \\
$\mathrm{Ca}^{2+}$ & 0.3 \\
$\mathrm{H}_{2} \mathrm{PO}_{4}{ }^{-}$ & 0.8 \\
$\mathrm{Fe}^{2+}$ & 0.3 \\
$\mathrm{Fe}^{3+}$ & 0.1 \\
\hline
\end{tabular}

solubility of $\mathrm{Si}$ in solution at a $\mathrm{pH}$ of 5 as a function of the Ca content of water is shown in Fig. 10. In this calculation, the activity coefficient of ions was determined using Debye Hückel theory [17, 18], and the calculated activity coefficients for $\mathrm{Si}$ and the other elements used in this study are summarized in Table 4. According to Fig. 10, the solubility of $\mathrm{Si}$ in water could be governed by $\mathrm{CaH}_{2} \mathrm{SiO}_{4}$ despite of any solid that has been leached, and a higher concentration of $\mathrm{Ca}^{2+}$ dissolved from $1 \mathrm{~g}$ of $\mathrm{C} 2 \mathrm{~S}-\mathrm{C} 3 \mathrm{P}$ led to a lower content of soluble $\mathrm{Si}$ compared to that of $1 \mathrm{~g}$ of fertilizers. Therefore, the soluble Si that dissolved from the $\mathrm{C} 2 \mathrm{~S}-\mathrm{C} 3 \mathrm{P}$ in $1 \mathrm{~g}$ of fertilizer could be higher than that from $1 \mathrm{~g}$ of $\mathrm{C} 2 \mathrm{~S}-\mathrm{C} 3 \mathrm{P}$ alone, and this is the reason why the dissolved masses of Si from fertilizers are higher than those calculated values as shown in Fig. 9. In addition, because both the fertilizers and the $\mathrm{C} 2 \mathrm{~S}-\mathrm{C} 3 \mathrm{P}$ showed similar results, the effect of quickly dissolved $\mathrm{Ca}$ from free $\mathrm{CaO}$ on the soluble Si was not significant.

$\mathrm{Ca}_{2} \mathrm{SiO}_{4}+4 \mathrm{H}^{+}=2 \mathrm{Ca}^{2+}+\mathrm{H}_{2} \mathrm{SiO}_{3}^{0}+\mathrm{H}_{2} \mathrm{O} \quad \log K=27.6$

$\mathrm{H}_{2} \mathrm{SiO}_{3}=\mathrm{H}_{2} \mathrm{SiO}_{3}^{0} \quad \log K=-1.8$

$\mathrm{CaH}_{2} \mathrm{SiO}_{4}+2 \mathrm{H}^{+}=\mathrm{Ca}^{2+}+\mathrm{H}_{2} \mathrm{SiO}_{3}^{0}+\mathrm{H}_{2} \mathrm{O} \quad \log K=4.6$

The leaching behavior of Fe is shown in Fig. 11. Fe was not dissolved from any mineralogical phase including metallic $\mathrm{Fe}$, except for the $\mathrm{C}-\mathrm{S}-\mathrm{Fe}^{2+}$ phase. The leaching behavior of Fe from fertilizer made of steelmaking slag is shown in Fig. 12 in comparison with the values calculated by the same method as in Eq. (2). The dissolved mass of Fe calculated by Eq. (2) after 120 min agreed well with that of each brand when the $\mathrm{Fe}$ oxide was assumed to be $\mathrm{FeO}$. Although the $\mathrm{Fe}^{2+} / \mathrm{Fe}^{3+}$ ratio in $\mathrm{Fe}$ oxide in the $\mathrm{C}-\mathrm{S}-\mathrm{F}$ phase of fertilizer made of steelmaking slag was unknown, a clear relationship was observed between the dissolution of $\mathrm{Fe}$ and the mass fraction of the $\mathrm{C}-\mathrm{S}-\mathrm{F}$ phase, as shown in Fig. 13. In addition, a clear relation was also found between the dissolution of $\mathrm{Fe}$ and the $\mathrm{Fe}^{2+} / \mathrm{Fe}^{3+}$ ratio in $\mathrm{Fe}$ oxide in fertilizer made of steelmaking slag as shown in Fig. 14. Therefore, the source of Fe dissolved into aqueous solution would be the $\mathrm{C}-\mathrm{S}-\mathrm{F}$ phase, and the $\mathrm{Fe}^{2+} / \mathrm{Fe}^{3+}$ ratio in the other phase is an important factor.

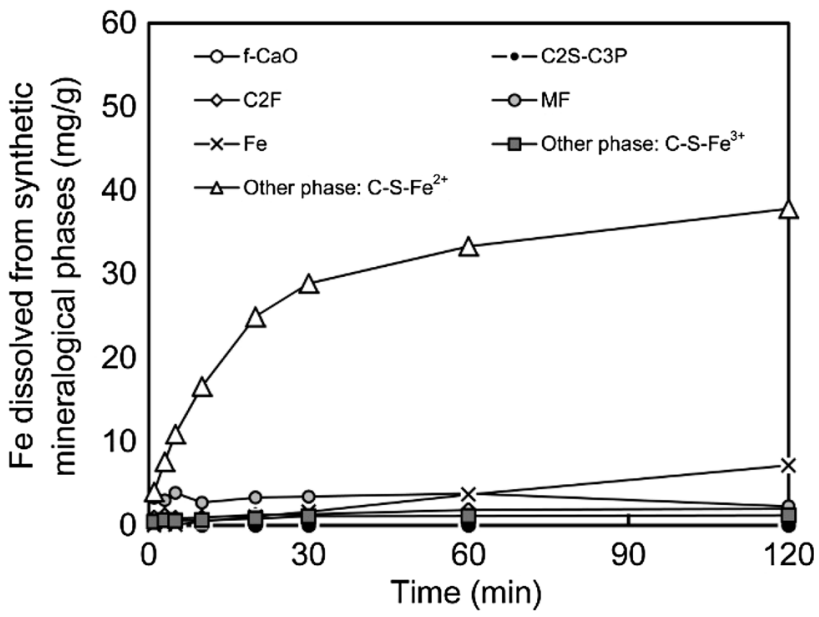

Fig. 11 Leaching behavior of $\mathrm{Fe}$ in aqueous solution from each mineralogical phase

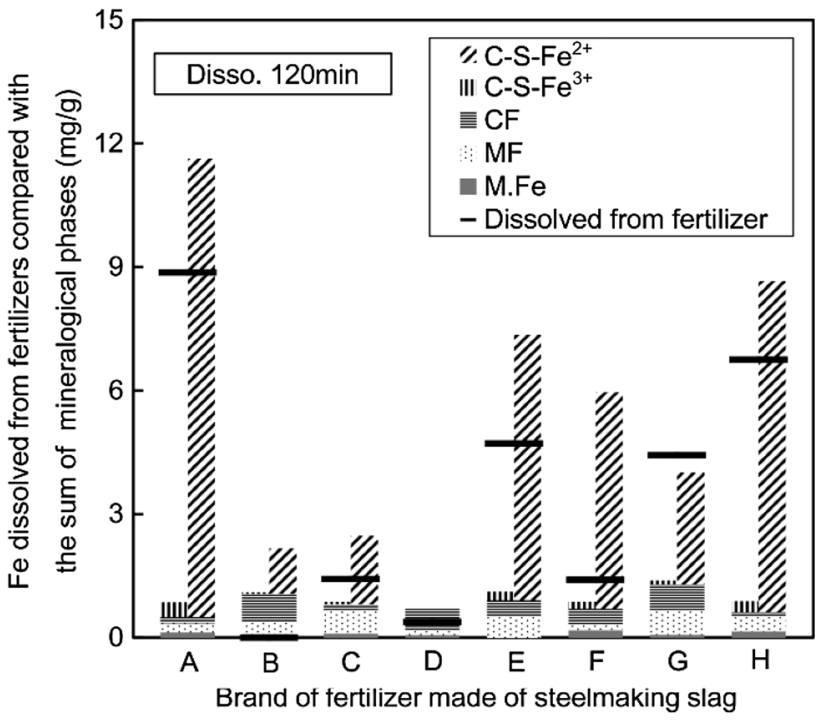

Fig. 12 Mass of Fe dissolved from each fertilizer made of steelmaking slag, comparing with the calculated value

The leaching behavior of $\mathrm{P}$ from mineralogical phase is shown in Fig. 15. It could be considered that $\mathrm{P}$ was dissolved from the $\mathrm{C} 2 \mathrm{~S}-\mathrm{C} 3 \mathrm{P}$ phase. The leaching behavior of $\mathrm{P}$ from the fertilizer made of steelmaking slag is shown in Fig. 16 in comparison with the values calculated by the same method as Eq. (2). The calculated values were larger than the actual values for every brand. The reason is thought to be that excess $\mathrm{Ca}$ dissolved from free $\mathrm{CaO}$ reacted with dissolved $\mathrm{P}$ to form a hydro-compound with low solubility of $\mathrm{P}$ in water. The relationship between soluble $\mathrm{P}$ and $\mathrm{Ca}$ in water was calculated on the basis of Eqs. (6) and (7) $[15,16,19]$. The result is shown in Fig. 17 in comparison with experimental data for the fertilizers, $\mathrm{C} 2 \mathrm{~S}-\mathrm{C} 3 \mathrm{P}$, and $\mathrm{C}-\mathrm{S}-\mathrm{Fe}^{2+}$ after leaching for $120 \mathrm{~min}$. 


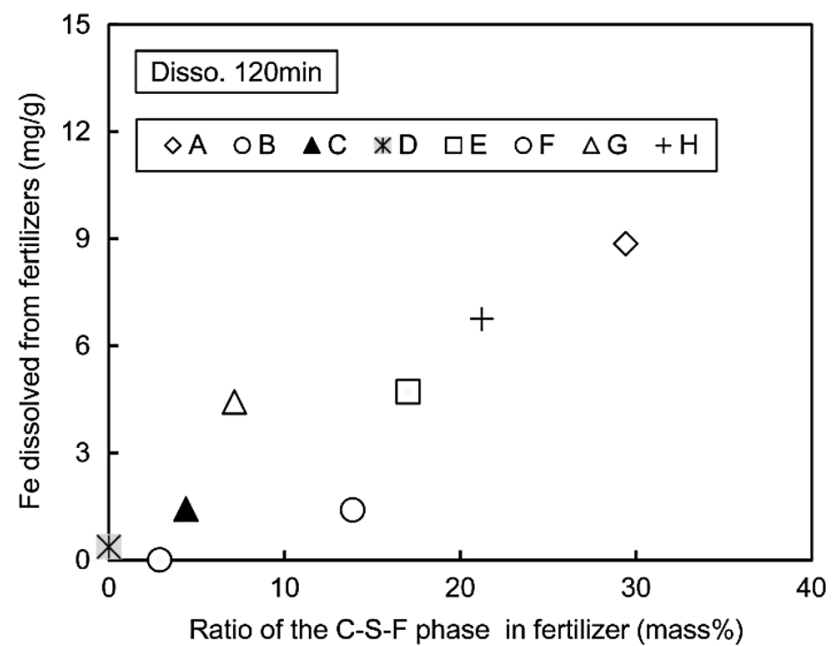

Fig. 13 Relationship between the dissolution of $\mathrm{Fe}$ and the mass fraction of the $\mathrm{C}-\mathrm{S}-\mathrm{F}$ phase in fertilizer made of steelmaking slag

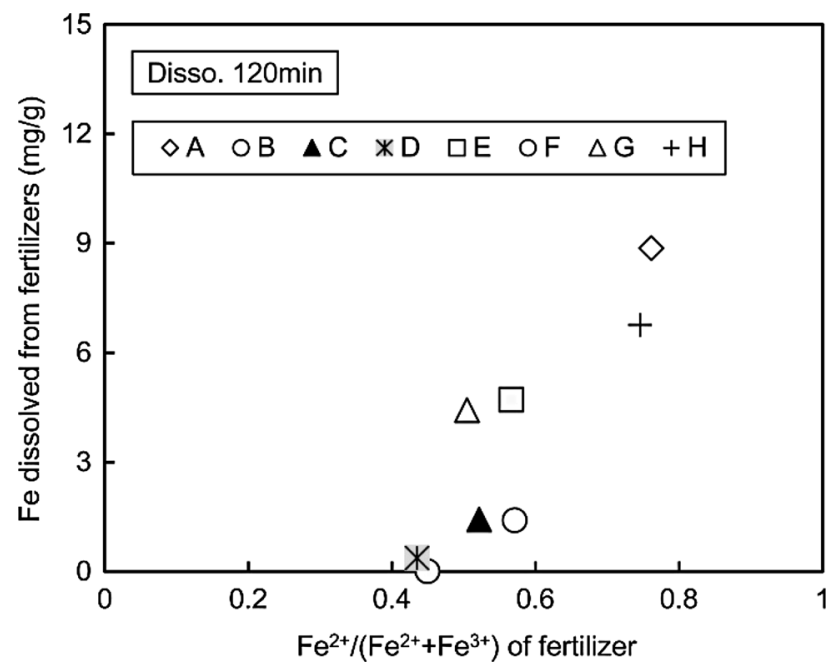

Fig. 14 Relationship between the dissolution of $\mathrm{Fe}$ and the $\mathrm{Fe}^{2+}$ / $\mathrm{Fe}^{3+}$ ratio in $\mathrm{Fe}$ oxide in fertilizer made of steelmaking slag

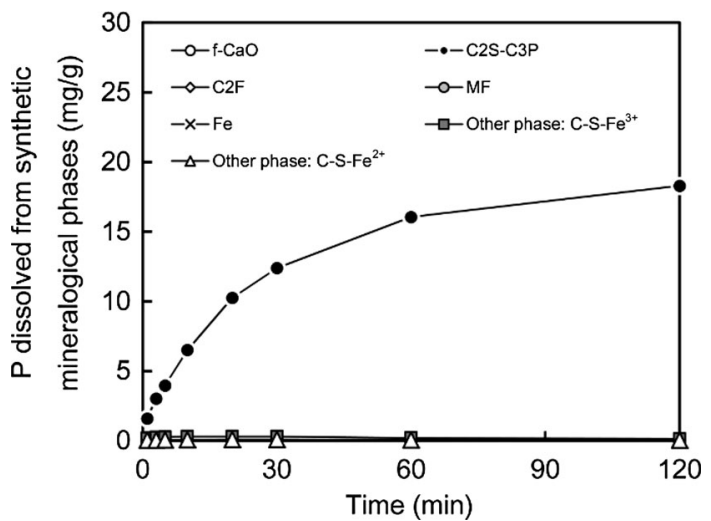

Fig. 15 Leaching behavior of $\mathrm{P}$ in aqueous solution from each mineralogical phase

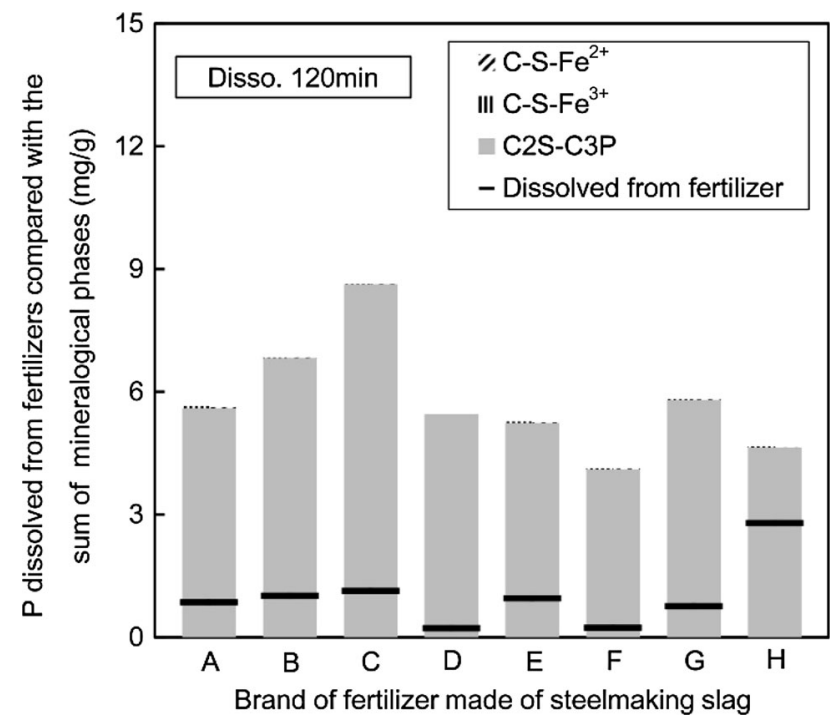

Fig. 16 Mass of $\mathrm{P}$ dissolved from each fertilizer made of steelmaking slag, comparing with the calculated value

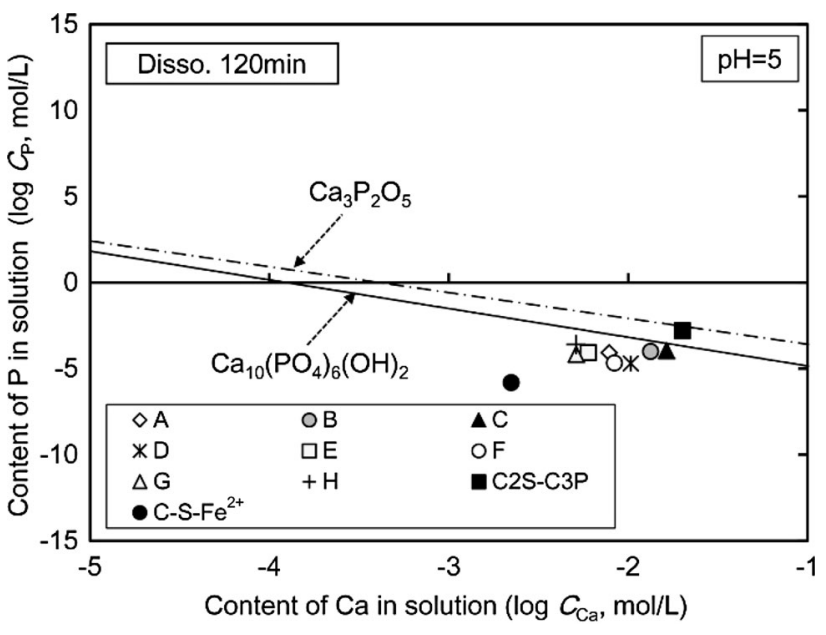

Fig. 17 Effect of dissolved $\mathrm{Ca}$ on the solubility of $\mathrm{P}$ in aqueous solution, comparing with experimental results at $120 \mathrm{~min}$

Compared to the results for $\mathrm{C} 2 \mathrm{~S}-\mathrm{C} 3 \mathrm{P}$ without free $\mathrm{CaO}$, those for the fertilizers are obviously located below the equilibrium line of $3 \mathrm{CaO} \cdot \mathrm{P}_{2} \mathrm{O}_{5}$ but close to that of $\mathrm{Ca}_{10}\left(\mathrm{PO}_{4}\right)_{6}(\mathrm{OH})_{2}$. Therefore, when the free $\mathrm{CaO}$ dissolved together with $\mathrm{C} 2 \mathrm{~S}-\mathrm{C} 3 \mathrm{P}$, which is exactly the case in fertilizers, the quickly released $\mathrm{Ca}^{2+}$ from free $\mathrm{CaO}$ could react with the $\mathrm{P}$ that dissolved next from $\mathrm{C} 2 \mathrm{~S}-\mathrm{C} 3 \mathrm{P}$, decreasing the amount of soluble $\mathrm{P}$.

$$
\begin{aligned}
& \mathrm{Ca}_{3} \mathrm{P}_{2} \mathrm{O}_{8}+4 \mathrm{H}^{+}=2 \mathrm{H}_{2} \mathrm{PO}_{4}^{-}+3 \mathrm{Ca}^{2+} \quad \log K=8.1 \\
& \mathrm{Ca}_{10}\left(\mathrm{PO}_{4}\right)_{6}(\mathrm{OH})_{2}+14 \mathrm{H}^{+}=6 \mathrm{H}_{2} \mathrm{PO}_{4}^{-}+10 \mathrm{Ca}^{2+} \\
& \quad+2 \mathrm{H}_{2} \mathrm{O} \quad \log K=25.1
\end{aligned}
$$

In comparison, the dissolved $\mathrm{Si}$ was not significantly affected by free $\mathrm{CaO}$ as mentioned, this can be explained by comparing the equilibrium $\mathrm{Ca}^{2+}$ concentration on the 


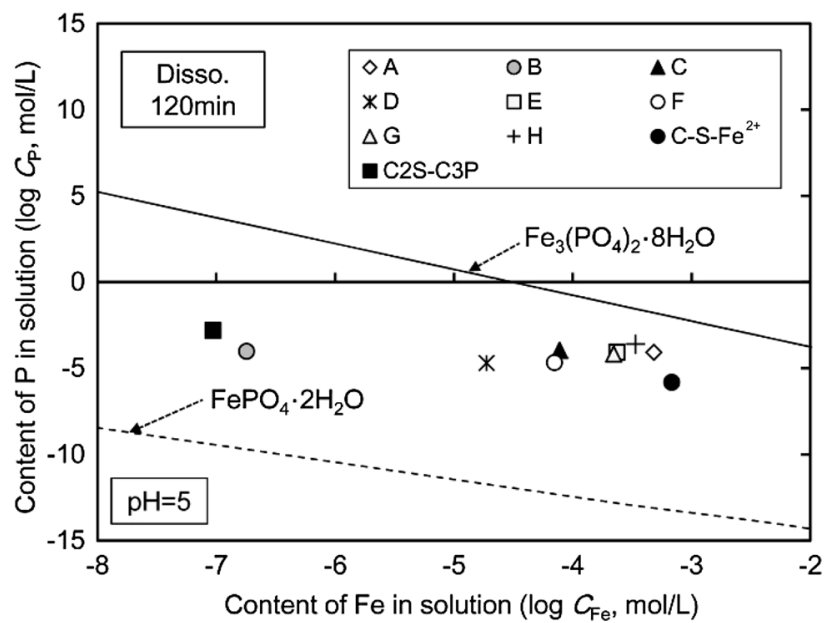

Fig. 18 Effect of dissolved $\mathrm{Fe}$ on the solubility of $\mathrm{P}$ in aqueous solution, comparing with experimental results at $120 \mathrm{~min}$

basis of Eqs. (5) and (7). When assuming the activities of dissolved $\mathrm{P}$ and $\mathrm{Si}$ are 1, the $\log K$ for Eqs. (5) and (7) can be expressed as the relation between the activity of $\mathrm{Ca}^{2+}$ and $\mathrm{pH}$, as shown in Eqs. (8) and (9). Here, the $a$ means activity. At same $\mathrm{pH}$, the relation between the equilibrium $\mathrm{Ca}^{2+}$ concentration according to Eqs. (5) and (7) can be obtained as shown in Eq. (10). Here, the $C$ means concentration, mol/L. Therefore, the $C_{\mathrm{Ca}^{2+}}^{(5)}$ is 10 times higher than $C_{\mathrm{Ca}^{2+}}^{(7)}$, and then the dissolved $\mathrm{P}$ is more sensitive to the excess $\mathrm{Ca}$ dissolved from free- $\mathrm{CaO}$ than that of $\mathrm{Si}$.

$\log K_{(5)}=\log a_{\mathrm{Ca}^{2+}}^{(5)}+2 \mathrm{pH}=4.6$

$\log K_{(7)}=10 \times \log a_{\mathrm{Ca}^{2+}}^{(7)}+14 \mathrm{pH}=25.1$

$C_{\mathrm{Ca}^{2+}}^{(5)}=10 \times\left[C_{\mathrm{Ca}^{2+}}^{(7)}\right]^{1.4}$

In addition, the easily dissolvable $\mathrm{C}-\mathrm{S}-\mathrm{Fe}^{2+}$ phase, which contributed to the dissolution of $\mathrm{Ca}, \mathrm{Si}$, and $\mathrm{Fe}$, showed a content of soluble $\mathrm{P}$ even lower than that of $\mathrm{Ca}_{10}\left(\mathrm{PO}_{4}\right)_{6}(\mathrm{OH})_{2}$. This is because, in addition to $\mathrm{Ca}$, the existence of $\mathrm{Fe}$ cations in aqueous solution could also decrease the solubility of $\mathrm{P}[20,21]$. The relation between dissolved $\mathrm{P}$ and $\mathrm{Fe}$ in water was calculated using Eqs. (11) and (12) $[15,16,19]$, and the result is shown in Fig. 18. The results for fertilizers were similar and independent of the amount of dissolved $\mathrm{Fe}$, indicating that the effect of dissolved $\mathrm{Ca}$ on soluble $\mathrm{P}$ was stronger than that of $\mathrm{Fe}$ for fertilizers that contained free $\mathrm{CaO}$. For the $\mathrm{C}-\mathrm{S}-\mathrm{Fe}^{2+}$ phase, the amount of dissolved $\mathrm{Fe}$ was the highest but that of dissolved $\mathrm{Ca}$ was the lowest; therefore, there is a high possibility that the dissolved $\mathrm{P}$ formed hydro-compounds with $\mathrm{Fe}$ cations during the dissolution of the $\mathrm{C}-\mathrm{S}-\mathrm{Fe}^{2+}$ phase.

$$
\begin{aligned}
& \mathrm{Fe}_{3}\left(\mathrm{PO}_{4}\right)_{2} \cdot 8 \mathrm{H}_{2} \mathrm{O}+4 \mathrm{H}^{+}=2 \mathrm{H}_{2} \mathrm{PO}_{4}^{-}+3 \mathrm{Fe}^{2+}+8 \mathrm{H}_{2} \mathrm{O} \\
& \quad \log K=4.7
\end{aligned}
$$

$$
\begin{aligned}
& \mathrm{FePO}_{4} \cdot 2 \mathrm{H}_{2} \mathrm{O}+2 \mathrm{H}^{+}=\mathrm{H}_{2} \mathrm{PO}_{4}^{-}+\mathrm{Fe}^{3+}+2 \mathrm{H}_{2} \mathrm{O} \\
& \quad \log K=-7.6
\end{aligned}
$$

\section{Conclusions}

To produce fertilizer made of steelmaking slag, the combination of mineralogical phases should be appropriate not only for refining at high temperature but also for supplementing nutrient elements in paddy fields. In this research, first, the variations in the chemical composition and mineralogical structure of various brands of fertilizer made of steelmaking slag were investigated. Second, the dissolution behavior of each mineralogical phase in fertilizer made of steelmaking slag into water that simulates the early stage of flooding conditions was examined. The following results were obtained.

1. The basicity of the fertilizer made of steelmaking slag varied from 1.4 to 4.1 and the free $\mathrm{CaO}$ content ranged from 1.6 to 8.5 mass\% depending on the brand. The ranges of total $\mathrm{Fe}$ content and $\mathrm{Fe}^{2+} / \mathrm{Fe}^{3+}$ ratio are $10.2-23.5$ mass $\%$ and $0.8-3.2$, respectively.

2. In every brand, $2 \mathrm{CaO} \cdot \mathrm{SiO}_{2}$ which formed a solid solution with $3 \mathrm{CaO} \cdot \mathrm{P}_{2} \mathrm{O}_{5}(\mathrm{C} 2 \mathrm{~S}-\mathrm{C} 3 \mathrm{P})$; the $\mathrm{MF}, \mathrm{CF}$, free $\mathrm{CaO}$, metallic $\mathrm{Fe}$, and the other phase which included liquid phases at the refining temperature were observed. The major phase was the $\mathrm{C} 2 \mathrm{~S}-\mathrm{C} 3 \mathrm{P}$ phase, and its fraction was 22.5-47.2 mass\% depending on the basicity.

3. It was found that free $\mathrm{CaO}$ dissolved completely in a short time and $\mathrm{C} 2 \mathrm{~S}-\mathrm{C} 3 \mathrm{P}$ phase dissolved slowly for about $1 \mathrm{~h}$. In addition, $\mathrm{Ca}$ was also supplied from the $\mathrm{C}-\mathrm{S}-\mathrm{Fe}^{2+}$ phase, but dissolution of the $\mathrm{C}-\mathrm{S}-\mathrm{Fe}^{3+}$ phase was negligible. The dissolved mass of $\mathrm{Ca}$ estimated by the dissolution of each phase agreed well with that for each brand of fertilizer made of steelmaking slag.

4. Fe was not dissolved from any mineralogical phase including metallic $\mathrm{Fe}$ except for the $\mathrm{C}-\mathrm{S}-\mathrm{Fe}^{2+}$ phase. Although, the $\mathrm{Fe}^{2+} / \mathrm{Fe}^{3+}$ ratio in $\mathrm{Fe}$ oxides in the $\mathrm{C}-\mathrm{S}-$ $F$ phase of the fertilizer made of steelmaking slag was not known, a clear relationship was observed between the dissolution of $\mathrm{Fe}$ and the mass fraction of the other phase as well as the $\mathrm{Fe}^{2+} / \mathrm{Fe}^{3+}$ ratio in $\mathrm{Fe}$ oxide in fertilizer made of steelmaking slag.

5. Both $\mathrm{Si}$ and $\mathrm{P}$ were dissolved mainly from $\mathrm{C} 2 \mathrm{~S}-\mathrm{C} 3 \mathrm{P}$ solid solution. The dissolved mass of $\mathrm{P}$ estimated as the sum of the mineralogical phases was higher than that of the fertilizers, but in contrast, that of $\mathrm{Si}$ was lower. This could be explained as follows: first, for fertilizers, excess $\mathrm{Ca}^{2+}$ dissolved from free $\mathrm{CaO}$ increased the share of $\mathrm{Ca}$ in the dissolved $\mathrm{Ca}: \mathrm{Si}: \mathrm{P}$ ratio compared to that in $\mathrm{C} 2 \mathrm{~S}-\mathrm{C} 3 \mathrm{P}$ alone, and this 
excess $\mathrm{Ca}^{2+}$ reacted with $\mathrm{P}$ precedence over $\mathrm{Si}$ to form $\mathrm{Ca}_{10}\left(\mathrm{PO}_{4}\right)_{6}(\mathrm{OH})_{2}$ which showed lower $\mathrm{P}$ solubility than $3 \mathrm{CaO} \cdot \mathrm{P}_{2} \mathrm{O}_{5}$ in water. Second, for $\mathrm{C} 2 \mathrm{~S}-\mathrm{C} 3 \mathrm{P}$, the amount of dissolved $\mathrm{Ca}$ was larger than that dissolved from fertilizers with the same amount, therefore, the amount of soluble $\mathrm{Si}$ in water which obeyed the equilibrium of $\mathrm{CaH}_{2} \mathrm{SiO}_{4}$ was decreased. This high $\mathrm{Ca}^{2+}$ content did not decrease the amount of soluble $\mathrm{P}$, as the ratio of dissolved $\mathrm{Ca}: \mathrm{Si}: \mathrm{P}$ still followed the dissolution of $\mathrm{C} 2 \mathrm{~S}-\mathrm{C} 3 \mathrm{P}$, and there was no excess $\mathrm{Ca}^{2+}$.

Acknowledgments The authors appreciate the financial support of the Iron \& Steel Institute of Japan for "ISIJ Innovative Program for Advanced Technology."

\section{References}

1. Association of Agriculture and Forestry Statistics (2012) Pocket handbook for fertilizer. Japan

2. Division of Basic research on Slag Utilization (1979) Properties and utilization of ironmaking and steelmaking slags. Tetsu-toHagané 65:1787-1811

3. Kitamura S, Ito T, Maruoka N, Shibata H (2012) Recovery of paddy field damaged by tsunami using steelmaking slag. Kinzoku 82(11):1011-1015

4. Futatsuka T, Shitogiden K, Miki T, Nagasaka T, Hino M (2003) Dissolution behavior of elements in steelmaking slag into artificial seawater. Tetsu-to-Hagané 89:382-387

5. Hayashi A, Asaoka S, Watanabe T, Kaneko R, Takahashi K, Miyata Y, Kim K, Yamamoto T, Inoue R, Ariyama T (2012) Mechanism of suppression of sulfide ion in seawater using steelmaking slag. Tetsu-to-Hagané 98:618-625. doi:10.2355/tet sutohagane.98.618

6. Ito K (2015) Steelmaking slag for fertilizer use. Nippon Steel \& Sumitomo Metal Technical Report 109, pp 130-136

7. Ito T, Nasu K, Saito M, Kitamura S (2014) Productivity improvement of saline paddy soils caused by seawater inflow with steelmaking slag fertilizer. CAMP-ISIJ 27:322

8. Maruoka N, Okubo M, Shibata H, Gao X, Ito T, Kitamura S (2015) Improvement of desalted paddy soil by the application of fertilizer made of steelmaking slag (Recovery of a paddy field damaged by the tsunami using fertilizer made of steelmaking slag-1). Tetsu-to-Hagané 101:445-456. doi:10.2355/tetsutoha gane.TETSU-2014-131

9. Okubo M, Maruoka N, Shibata H, Gao X, Ito T, Kitamura S (2015) Long-term dissolution characteristics of various fertilizers made of steelmaking slag in a desalted paddy soil environment (Recovery of a paddy field damaged by the tsunami using fertilizer made of steelmaking slag-2). Tetsu-to-Hagané 101:457464. doi:10.2355/tetsutohagane.TETSU-2014-132

10. Gao X, Maruoka M, Shibata H, Ito T, Kitamura S (2015) Application of steelmaking slag on the recovery of degraded paddy field. In: Proceedings of the 6th International Congress on the Science and Technology of Steelmaking, pp 958-961

11. Aimoto M, Kanehashi K, Fujioka Y (2015) Analytical Technologies for steel slag. Nippon Steel \& Sumitomo Metal Technical Report 109, pp 16-22

12. Japanese Industrial Standards Committee (1995) Iron oresmethod for determination of acid soluble iron (II) content, JIS M8213-1995

13. Kato M, Hari T, Saito S, Shibukawa M (2014) Determination of free lime in steelmaking slags by use of ethylene glycol extraction/ICP-AES and thermogravimetry. Tetsu-to-Hagané 100:340345. doi:10.2355/tetsutohagane.100.340

14. Arjunan P, Kumar A (1994) Rapid techniques for determination of free lime and free magnesia in cement clinker and portlandite in hydrates. Cem Concr Res 24:343-352. doi:10.1016/00088846(94)90061-2

15. Dean J (1979) Lange's handbook of chemistry, 12th edn. McGraw-Hill, New York

16. Lindsay W (1979) Chemical equilibria in soils. Wiley, New York

17. Debye P, Hückel E (1923) The theory of electrolytes. I. Lowering of freezing point and related phenomena. Physikalische Zeitschrift 24:185-206

18. Kielland J (1937) Individual activity coefficients of ions in aqueous solution. J Am Chem Soc 59:1675-1678

19. Iglesia A (2009) Estimating the thermodynamic properties of phosphate minerals at high and low temperature from the sum of constituent units. Estud Geol 65:109-119. doi:10.3989/egeol. 39849.060

20. Krom M, Kress N, Brenner S, Gordon L (1991) Phosphorus limitation of primary productivity in the eastern Mediterranean Sea. Limnol Oceanogr 36:424-432. doi:10.4319/lo.1991.36.3.0424

21. De-Bashan L, Bashan Y (2004) Recent advances in removing phosphorus from wastewater and its future use as fertilizer. Water Res 38:4222-4246. doi:10.1016/j.watres.2004.07.014 